\title{
L(+)-Lactic Acid Recovery from Cassava Bagasse Based Fermented Medium Using Anion Exchange Resins
}

\author{
Rojan P. John, K. Madhavan Nampoothiri * and Ashok Pandey \\ Biotechnology Division; National Institute for Interdisciplinary Science and Technology; \\ madhavan85@hotmail.com; Trivandru; Kerala - India
}

\begin{abstract}
The properties of the ion exchange resins, Amberlite IRA 402, a strong anion exchange resin and IRA 67, a weak anion exchange resin were determined to evaluate their comparative suitability for lactic acid recovery from fermented cassava bagasse. Data on binding capacities and recovery proved that weak base resin in chloride form was the most favourable ones for lactic acid recovery from aqueous solutions and fermentation media. Fermented media obtained through simultaneous saccharification and fermentation of cassava bagasse starch hydrolysate based medium were used for lactic acid recovery study using weak base resin column. Amberlite IRA 67 had much more efficiency than Amberlite IRA 402 to recover lactic acid. Like in other reports, due to the presence of nutrients and ions other than lactate, the binding capacity was slightly lesser while using fermented media ( 93\%) instead of aqueous lactic acid solutions ( 98\%).
\end{abstract}

Key words: L(+) lactic acid, lactobacilli, anion exchage resin, cassava bagasse

\section{INTRODUCTION}

Lactic acid can be used for products that potentially have very large-volume uses in industrial applications and consumer products. It is usually used as a $\mathrm{pH}$ adjusting ingredient or as a preservative (either as antioxidant or for control of pathogenic micro-organisms). Lactic acid is widely used for inhibiting pathogenic bacteria on animal carcasses like beef, pork and poultry during the slaughtering process. Potassium lactate, sodium lactate and calcium lactate are the neutralized salts of lactic acid. Potassium lactate is used in many fresh and cooked meat products for shelf life control, color preservation and reduction of sodium content. Sodium lactate has a mild saline taste and is therefore suitable for flavour enhancement in meat products as well. Calcium lactate is popular for fortification and mproved texture in emulsified meat products like frankfurters.

The primary classes of consumer products are polymers for plastics and fibers, solvents for formulations and cleaning and oxygenated industrial chemicals. Lactic acid production has attracted increasing attention, primarily because of the desirable biocompatibility and biodegradability of its polymer and copolymers. Nature Works LLC, the current leader of lactic acid-based polymers and products, has stated publicly its belief that the PLA market will reach 500,000 (metric) tonnes per year worldwide by 2010 , and the construction of two additional PLA plants are

\footnotetext{
* Author for correspondence
} 
being considered presently (John et al., 2007a, Wee et al., 2006). Lactic acid consumption in chemical applications, which include PLA polymer and new green solvents, such as ethyl lactate, is expected to expand $19 \%$ per year (John et al., 2007a).

Separation process takes a large part of the total cost in lactic acid production. Commercially lactic acid is recovered as calcium lactate by precipitation. The disadvantages of this method are high product loss during crystallization and environmental problems caused by the formation of a large quantity of calcium sulphate (gypsum). Typically lactic acid for polymers, pharmaceuticals or food derivatives requires further purifications. Many separation methods such as electrolysis, membrane filtration, ion exchange, and aqueous two-phase system extraction have been studied for lactic acid recovery (Boniardi et al., 1997; Siebold et al., 1995; Chen and Lee, 1996; Evangelista and Nikolov, 1996; Known et al., 1996; Planas et al., 1999; Jeantet et al., 1996; Russo et al., 1996). However, comparatively high amounts of solvents are needed for extraction, and toxic effects are provoked by solvents. In the electrodialysis units, cells adhered to membranes during the process, leading to decreased efficiency in the overall recovery system (Nomura et al., 1987; Davison and Scott, 1992; Zihao and Kefeng, 1995; Moldes et al., 2003). Lactic acid from fermentation broth can be recovered using anion polymeric adsorbents, which were strong, moderate, or weak basic anion exchange resins adsorbing lactic acid below and above of its pKa (Moldes et al., 2003; Kulprathipanja and Oroshar, 1991). The advantage of this process is that acidification of fermentation broth is not required before adsorption. Adsorption of ion exchange resin is a practical method in industry because of its economy and facility, reduction in consumption of chemicals and production of wastes. This separation method can also be coupled with fermentation process. We made an attempt on the recovery of lactic acid from fermented medium based on cassava bagasse, a locally available agro residue generated from cassava starch industry.

\section{MATERIALS AND METHODS}

\section{Microorganisms}

Homo fermentative L. delbrueckii NCIM 2025 producing L-lactic acid was procured from National Collection of Industrial Microorganism, National Chemical Laboratory, Pune, India and $L$. casei NCIMB 3254 was obtained from National Collection of Industrial and Marine Bacteria Ltd., Aberdeen, Scotland. Strains were maintained as stab culture at $4^{\circ} \mathrm{C}$ on MRS agar and when required the strains were revived at $37^{\circ} \mathrm{C}$ for $18 \mathrm{~h}$ in MRS broth.

\section{Enzymes}

For the enzymatic hydrolysis of cassava bagasse, commercially available (Rashesh and Co., Mumbai,India) $\alpha$-amylase (Termamyl, 5000 $\mathrm{IU} / \mathrm{mL}$ ) and glucoamylase (AMG, $2000 \mathrm{IU} / \mathrm{mL}$ ) were used.

\section{Lactic acid production from cassava bagasse starch hydrolysate}

Cassava bagasse was collected from Varalakshmi starch industries, Selam in Tamil Nadu. For submerged fermentation, cassava bagasse $(7.5 \%$, w/v) was gelatinised and liquefied with $0.2 \mathrm{ml}$ alpha amylase at $90{ }^{\circ} \mathrm{C}$ for $30 \mathrm{~min}$. and saccharified with $0.2 \mathrm{ml}$ glucoamylase at $60{ }^{\circ} \mathrm{C}$ for $70 \mathrm{~min}$. Hydrolyzate containing $4 \%$ reducing sugar was supplemented with yeast extract $(0.5 \%$, w/v), ammonium chloride $(0.5 \%$, w/v). $2.5 \%$, w/v $\mathrm{CaCO}_{3}$ was added for buffering. $2 \%$, v/v inoculum containing $10^{9} \mathrm{CFU} / \mathrm{ml}$ was used for inoculation which was then incubated at $37^{\circ} \mathrm{C}$ for $120 \mathrm{~h}$.

\section{Simultaneous Saccharification and Fermentation}

The production medium was made by supplementing the raw cassava bagasse $(15.5 \%$ $\mathrm{w} / \mathrm{v}$ ) in $100 \mathrm{~mL}$ distilled water with yeast extract $(0.5 \% \mathrm{w} / \mathrm{v})$ and ammonium chloride $(0.5 \% \mathrm{w} / \mathrm{v})$. Tween-40 $(0.1 \% \mathrm{v} / \mathrm{v})$ was added as surfactant and $\mathrm{CaCO}_{3}(4 \% \mathrm{w} / \mathrm{v})$ was added for buffering (to keep the medium $\mathrm{pH}$ between 5.5 and 6.5). It was autoclaved at $121^{\circ} \mathrm{C}(15 \mathrm{lb})$ for $15 \mathrm{~min}$. 
Subsequently, the sterile medium was inoculated with $2.5 \mathrm{~mL}$ preparatory culture $\left(18 \mathrm{~h}\right.$ old, $10^{9}$ $\mathrm{CFU} / \mathrm{mL}$ ) of $L$. delbrueckii and $L$. casei (1:1 ratio). Sufficient amounts of starch-hydrolyzing enzymes were also added with the inoculum. After thorough mixing, the flasks were incubated in static condition at $37^{\circ} \mathrm{C}$ in an environmental chamber (Sanyo, Japan) for three days.

\section{Preparation of synthetic solutions of lactic acid to be used for resin selection}

Samples of pre set concentrations were prepared from commercially available L(+)-lactic acid (Sigma, USA). The $\mathrm{pH}$ was adjusted to 5 by adding $10 \% \mathrm{Ca}(\mathrm{OH})_{2}$ and the samples were stored at $4{ }^{\circ} \mathrm{C}$ until use.

\section{Resin preparation}

Amberlite IRA-402, a strong basic exchanger (1.2 meq/mL exchange capacity) and IRA-67, a weakly basic exchanger $(1.6 \mathrm{meq} / \mathrm{mL}$ exchange capacity), are selected as the ion exchangers for the particular study. Amberlite IRA 67 is a weakly basic anion exchange resin with an unusually high capacity for large organics. Amberlite IRA 402 is mainly used for water conditioning, removal of weakly acidic contaminants etc. Before utilization, the resins were washed and converted into their $\mathrm{OH}^{-}$or $\mathrm{Cl}^{-}$forms. Resins in $\mathrm{OH}^{-}$form were obtained by washing the resins sequentially with 1 $\mathrm{N} \mathrm{NaOH}$ solution, distilled water, $1 \mathrm{~N} \mathrm{HCl}$ solution, distilled water, $1 \mathrm{~N} \mathrm{NaOH}$ solution and distilled water (until $\mathrm{pH}=7$ ). Because of their own nature, Amberlite IRA67 could not be obtained in $\mathrm{OH}^{-}$form (both resins remained in free base form at $\mathrm{pH}$ higher than 9). Resins in $\mathrm{Cl}^{-}$form were obtained by washing the resins sequentially with 1 $\mathrm{N} \mathrm{HCl}$ solution, distilled water, $1 \mathrm{~N} \mathrm{NaOH}$ solution, distilled water, $1 \mathrm{~N} \mathrm{HCl}$ solution and distilled water (until $\mathrm{pH}=7$ ). Aliquots of resins in $\mathrm{OH}^{-}$and $\mathrm{Cl}^{-}$forms were air dried and assayed for moisture by oven drying at $105{ }^{\circ} \mathrm{C}$ for $24 \mathrm{~h}$.

\section{Adsorption capacity of resins}

In the study of equilibrium, $1 \mathrm{~g}$ of wet resin of IRA 67 and IRA 402 with $\sim 65 \%$ moisture and 5 $\mathrm{ml}$ of two different concentration series of aqueous lactic acid solutions such as (IRA 67: 20, $40,60,80,100,120,130,140$ and $160 \mathrm{mg}$ and IRA 402: 20, 40, 60, 80, 100, 110,120, 140 and $160 \mathrm{mg}$ lactic acid/ $5 \mathrm{ml}$ ) were mixed for direct contact in $50 \mathrm{ml}$ flasks at $25{ }^{\circ} \mathrm{C}$. The initial $\mathrm{pH}$ of all samples was fixed at $\mathrm{pH} 5$. After $12 \mathrm{~h}$, samples of the supernatants were withdrawn and analysed for lactic acid by colorimetric method. Residual lactic acid concentrations in the solutions were measured and the amount of adsorbed L(+)-lactic acid per gram resin was calculated.

\section{Recovery of lactic acid}

In this study, $1 \mathrm{~g}$ of lactic acid loaded resin (125 mg/g Amberlite IRA 67 and 105 mg/g Amberlite IRA 402) added to $5 \mathrm{ml}$ of different elutants like 1 $\mathrm{N}$ solutions of $\mathrm{HCl}, \mathrm{H}_{2} \mathrm{SO}_{4}, \mathrm{NaCl}, \mathrm{NH}_{4} \mathrm{Cl}$, methanol and distilled water in test tubes. These tubes were shaked well in an incubator at $28{ }^{\circ} \mathrm{C}$ for $2 \mathrm{~h}$ and centrifuged $(\sim 3000 \times \mathrm{g}$ for $10 \mathrm{~min}$.) and the concentration of lactic acid in eluate was determined.

Based on the performance in adsorption and recovery of lactic acid, Amberlite IRA 67 was selected for the further studies. One gram of lactic acid loaded resin (125 mg/g Amberlite IRA 67) added to $3 \mathrm{ml}$ of different concentrations of methanol (0-90\%) and distilled water in test tubes. These tubes were shaken at $200 \mathrm{rpm}$ in a shaking incubator for $2 \mathrm{~h}$ and concentration of lactic acid in eluate was determined. Recovery of lactic acid was done with $1 \mathrm{~N} \mathrm{HCl}$.

\section{Ion exchange column}

A column (length, $27 \mathrm{~cm}$; i.d., $1.2 \mathrm{~cm}$ ) was packed with $\sim 14.5 \mathrm{~g}$ of resin (Amberlite IRA 67), filled with distilled water. An aqueous solution of lactic acid (43 g lactic acid/L) at $\mathrm{pH} 5$ was pumped at a flow rate of $0.3 \mathrm{ml} / \mathrm{min}$. Fractions of the effluent were collected and analyzed for lactic acid. The resin was considered to be saturated when the lactic acid concentration was less in the effluent and reached the value corresponding to the feed. The interstitial solution was removed by pumping distilled water until the lactic acid concentration of the effluent was below $0.1 \mathrm{~g} / \mathrm{l}$. Effect of methanol to reduce the loss on washing waschecked. Lactic acid recovery was achieved by pumping $1 \mathrm{~N} \mathrm{HCl}$ at a flow rate of $0.3 \mathrm{ml} / \mathrm{min}$ through the column. Samples of the effluent were collected and analysed for lactic acid until an outlet concentration below $0.1 \mathrm{~g} / \mathrm{l}$ was reached. Finally, a washing step was carried out using distilled water to remove the $\mathrm{HCl}$ contained in the interstitial space, and the column became ready for a new cycle. Different types of fermentation broth were also used along with the lactic acid solution. 


\section{Analysis}

Samples were withdrawn at desired intervals, treated, and diluted with $1 \mathrm{M} \mathrm{H}_{2} \mathrm{SO} 4$ to release lactic acid from calcium lactate. Total lactic acid ( $\mathrm{mg} / \mathrm{mL}$ fermentation medium) was estimated according to the colorimetric method of Barker and Summerson, 1941. The amount of reducing sugar was determined by the dinitrosalicylic acid method (Miller, 1959). Starch was estimated colorimetrically as described by Nampoothiri et al., 2003 using an aqueous iodine solution as a reagent; coloration of samples was measured on a UV spectrophotometer (Shimadzu, Japan) at 620 $\mathrm{nm}$. All the experiments were performed in triplicate.

\section{RESULTS AND DISCUSSION}

The suitability of an ion exchange resin for lactic acid recovery from SSF media depends on its physicochemical features including sorption capacity, its susceptibility and stability towards load/regeneration cycles. The capacity of the resins in their different forms was evaluated in the first part of this study. Resins were contacted with an aqueous solution containing lactic acid with initial $\mathrm{pH}$ adjusted to 5 by $\mathrm{Ca}(\mathrm{OH})_{2}$ addition. When equilibrium was reached, samples of supernatants were withdrawn and the capacities of the resins (denoted q, mg lactic acid/g resin) were calculated by the equation:

$$
\mathrm{q}=\mathrm{LA}_{0}-\mathrm{LA}_{\mathrm{f}} / \mathrm{w}
$$

Where, $\mathrm{LA}_{0}$ and $\mathrm{LA}_{\mathrm{f}}$ are initial and final lactic acid in the aqueous medium ( $\mathrm{mg}$ ) and $\mathrm{w}$ is weight of the resin $(\mathrm{g})$.

Figure 1 shows the capacities of the resins in their different forms. In $\mathrm{Cl}^{-}$form, the weak base resin presented the highest adsorption capacitiy. However, the strong base resin in $\mathrm{OH}^{-}$form had higher adsorption capacities than the weak base ones in free base form. Amberlite IRA 67 could not be obtained in $\mathrm{OH}_{-}^{-}$form (remained in free base form at $\mathrm{pH}$ higher than 9). Amberlite IRA 67 $\mathrm{Cl}^{-}$form and IRA $402 \mathrm{OH}^{-}$forms were selected for the other studies.

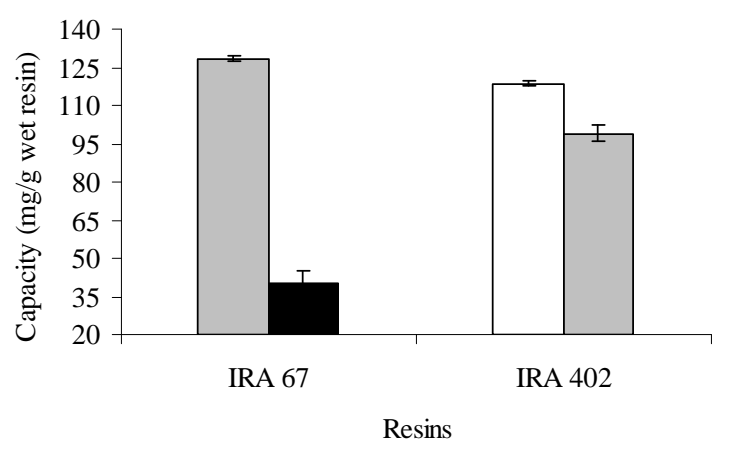

Figure 1 - Capacity of resin in free base, hydroxyl and chloride form of Amberlite IRA 67 and Amberlite IRA $402\left(\mathrm{Cl}^{-}\right.$form, $\square \mathrm{OH}^{-}$form, $\square$ Free base form, $\square$ ).

Figure 2 shows the capacity of the different resin forms to adsorb lactic acid from different concentrations of lactic acid. The result indicates that Amberlite IRA 67 has more adsorption capacity $(\sim 126 \mathrm{mg} / \mathrm{g}$ wet resin with more than 95 $\%$ lactic acid adsorption) than the Amberlite IRA $402(\sim 119 \mathrm{mg} / \mathrm{g}$ wet resin with more than $85 \%$ lactic acid adsorption). 


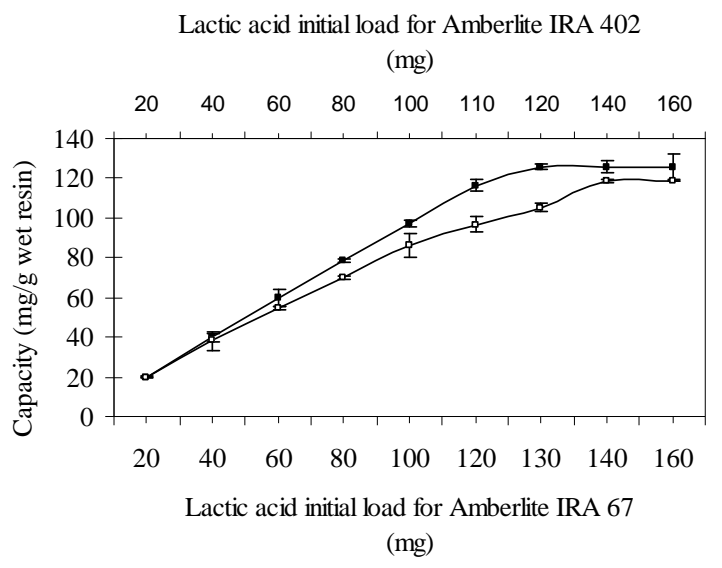

Figure 2 - Capacity of Amberlite IRA 67, concentration of lactic acid.

$1 \mathrm{~N} \mathrm{HCl}$ and $1 \mathrm{~N} \mathrm{H}_{2} \mathrm{SO}_{4}$ was best eluatants for Amberlite IRA 67 and Amberlite IRA 402 respectively. Almost complete recovery achieved by $\mathrm{H}_{2} \mathrm{SO}_{4}$ and $\mathrm{HCl}$ from Amberlite IRA 67 and Amberlite IRA 402 respectively. The amounts of recovered lactic acid are shown as columns and percentage of the recovery as line graph. Sulphate, a divalent anion, has stronger binding ability to monovalent cation of Amberlite IRA 402 resin than monovalent anion such as $\mathrm{Cl}^{-}$or $\mathrm{OH}^{-}$.

According to Cao et al., 2002 mixture of methanol and $\mathrm{H}_{2} \mathrm{SO}_{4}$ was not effective to elute $\mathrm{L}-(+)$-lactic acid. Methanol is an organic solvent with low dielectric constant and this probably reduced the elution by $\mathrm{H}_{2} \mathrm{SO}_{4}$. However, methanol was a good eluant for lactic acid adsorbed on VI-15, a weak basic anion exchange resin (Evangelista and Nikolov, 1996). Different characteristics in the elution of lactic acid are expected when different types of resins were used (Cao et al., 2002). The elution recovery of lactic acid from IRA-67 using methanol was only $9.6 \%$ and water was 22.3. Different methanol concentrations were used for washing step to study the efficacy and it could reduce the product loss in washing step as results shown on the Table 1.

Table 1- Effect of methanol on washing step during the recovery of lactic acid using Amberlite IRA 67.

\begin{tabular}{|c|c|c|c|c|c|c|}
\hline \multirow{3}{*}{ Solvent } & \multicolumn{6}{|c|}{ Lactic acid concentration } \\
\hline & \multirow{2}{*}{$\begin{array}{c}\text { Loading } \\
\text { (mg/ml) }\end{array}$} & \multirow{2}{*}{$\begin{array}{l}\text { Effluent } \\
\text { (mg) }\end{array}$} & \multirow{2}{*}{$\begin{array}{c}\text { Washing } \\
\text { (mg) }\end{array}$} & \multirow{2}{*}{$\begin{array}{l}\text { Elution } \\
(\mathrm{mg} / \mathrm{ml})\end{array}$} & \multicolumn{2}{|c|}{ Total lactic acid recovered } \\
\hline & & & & & $\begin{array}{c}\text { Concentration } \\
(\mathrm{mg})\end{array}$ & $\begin{array}{c}\text { Percentage } \\
\text { recovery }\end{array}$ \\
\hline Methanol (5\%) & 43 & 3 & 4.1 & 40.63 & 121.2 & 96.96 \\
\hline Methanol (10\%) & 43 & 3 & 2.6 & 41.13 & 123.4 & 98.7 \\
\hline Methanol (20\%) & 43 & 3 & 3.8 & 40.73 & 122.2 & 97.75 \\
\hline Methanol (50\%) & 43 & 3 & 5.9 & 40 & 120.1 & 96 \\
\hline Methanol (90\%) & 43 & 3 & 6.8 & 39.7 & 119.2 & 95 \\
\hline Water & 43 & 3 & 10.9 & 38.36 & 115.1 & 92 \\
\hline
\end{tabular}

Probably ion exchange mechanism was the main interaction mechanism in basic condition. Lactate ion can be adsorbed on IRA-67 resin by ion exchange and the eluate concentration decreased with methanol solution (highest reduction in lower concentration). This shows that methanol can also promote adsorption of lactic acid on IRA-67 resin.
The elution of lactic acid is affected by dielectric constant of solvent. On industrial point of view, water may be selected as a solvent for washing or washing step can be avoided to reduce the cost. Cassava bagasse, the agro industrial waste was proved as a potential carbon source for the production of lactic acid through submerged, 
solid-state and simultaneous sachharification fermentation (Rojan et al., 2005; John et al., 2006a; 2006b; 2006c; 2007b; 2007c; 2007d). Simultaneous saccharification fermentation has several advantages over solid-state and submerged fermentation using the hydrolyzate (John et al., 2006b; 2006c; 2007d). Column separations of different fermentation broth were compared with lactic acid solution. The adsorption performance was not interfered by salts components in fermentation broth. Although inorganic acid can be used for the adjustment of $\mathrm{pH}$, the $\mathrm{pH}$ should be adjusted by strong acidic resins before fermentation broth is adsorbed on weak basic resins because anions of inorganic acids compete with lactate anions to interfere adsorption of the resin (Cao et al., 2002; Evangelista and Nikolov; 1996). Resin adsorption is a crude separation method and it is impossible to obtain high product purity. As a result, it is important to decide how to arrange the refining steps. Glucose concentration do not affected lactic acid adsorption as there was no adsorption of glucose on amberlite IRA 400 (Cao et al., 2002). There was reduction in the capacity of resin IRA 67 in recovery of lactic acid from fermentation broth than the aqueous solution of pure lactic acid as shown in the Table 2 . Highest reduction was noticed in the case of sulphuric acid treated sample. The resin capacities of fermentation media decreased with respect to aqueous solutions, owing to both the exchange of ions other than lactate (for example, sulphate, phosphate, citrate and acetate) and to the adsorption of extraneous components (nutrients, enzymes, etc.) to the polymer (Moldes 2003). Thang and Novalin (2008) mentioned several advantages of chromatography such as reduction of the effluent volume and of the pollution load, avoidance of chemical regenerates and a significant decrease of energy consumption.

Table 2- Column separation of lactic acid from lactic acid solution and different fermentation broth at pH 5.

\begin{tabular}{|c|c|c|c|c|}
\hline Solution & $\begin{array}{c}\text { Conc. of Lactic acid } \\
(\mathrm{mg} / \mathrm{ml})\end{array}$ & Volume (ml) & $\begin{array}{c}\text { Total } \\
\text { amount (mg) }\end{array}$ & Recovery (\%) \\
\hline \multicolumn{5}{|c|}{ Lactic acid solution } \\
\hline Loading & 43 & 42 & 1806 & \\
\hline Effluent & 0.46 & 30 & 13.93 & 0.77 \\
\hline Washing & 0.168 & 60 & 10.08 & 0.56 \\
\hline Eluate & 17.82 & 100 & 1782 & 98.67 \\
\hline \multicolumn{5}{|c|}{ Fermented cassava bagasse hydrolysate (without buffering) } \\
\hline Loading & 22 & 86 & 1890 & \\
\hline Effluent & 1.35 & 30 & 40.5 & 2.1 \\
\hline Washing & 1.68 & 60 & 100.8 & 5.4 \\
\hline Eluate & 17.482 & 100 & 17482 & 92.5 \\
\hline \multicolumn{5}{|c|}{ Fermented cassava bagasse hydrolysate (with buffering) } \\
\hline Loading & 42 & 44.5 & 1870.5 & \\
\hline Effluent & 1.21 & 30 & 36.3 & 1.9 \\
\hline Washing & 1.45 & 60 & 72.5 & 3.9 \\
\hline Eluate & 17.61 & 100 & 1761.2 & 94.2 \\
\hline \multicolumn{5}{|c|}{ Fermented cassava bagasse hydrolysate (with buffering and treated with $\mathrm{H}_{2} \mathrm{SO}_{4}$ ) } \\
\hline Loading & 40 & 45 & 1800 & \\
\hline Effluent & 1.76 & 30 & 52.8 & 2.9 \\
\hline Washing & 1.215 & 60 & 72.9 & 4.1 \\
\hline Eluate & 16.743 & 100 & 1674.3 & 93 \\
\hline \multicolumn{5}{|c|}{ Simultaneous saccharified and Fermented cassava bagasse (with buffering) } \\
\hline Loading & 80 & 23 & 1840 & \\
\hline Effluent & 0.707 & 30 & 21.2 & 1.2 \\
\hline Washing & 1.047 & 60 & 62.8 & 3.4 \\
\hline Eluate & 17.56 & 100 & 1756 & 95.4 \\
\hline
\end{tabular}

\section{CONCLUSION}

The costs of recovery and purification account for almost $50 \%$ of the overall production costs in lactic acid fermentation and bringing a reduction in it being one of the most important challenges of lactic acid production (Evangelista and Nikolov; 1996; Zihao and Kefeng, 1995; Kaufman et al., 1995). Due to high affinity and susceptibility for regeneration, amberlite is one of the best means 
for the recovery of lactic acid. It can be concluded that Amberlite IRA 67 in chloride form showed a constructive performance for lactic acid recovery from fermentation media, in terms of affinity, capacity and susceptibility to regeneration.

\section{ACKNOWLEDGEMENTS}

One of the authors (RPJ) is deeply indebted to Council of Scientific and Industrial Research (CSIR) for the award of Senior Research Fellowship for doctoral studies. Authors are thankful to Varalakshmi Starch Industries, Salem, India for providing cassava bagasse for the studies.

\section{RESUMO}

As propriedades das resinas de troca iônica, da Amberlite IRA 402, uma resina de troca aniônica forte, e da IRA 67, uma resina de troca aniônica fraca, foram determinadas para se avaliar a adequabilidade comparativa delas à obtenção de ácido lático de bagaço de mandioca fermentado. Dados sobre a capacidade de ligação e sobre a obtenção provaram que a resina de base fraca na forma de cloreto era a mais adequada para a obtenção de ácido lático em soluções aquosas e meios de fermentação. Os meios de fermentação obtidos da sacarificação e da fermentação simultâneas de meios baseados hidrolisados de fécula de bagaço de mandioca foram usados para o estudo da obtenção de ácido lático usando uma coluna de resina de base fraca. A Amberlite IRA 67 mostrou-se muito mais eficaz do que a Amberlite IRA 402 para a obtenção de ácido lático. Como em outros relatórios, devido à presença de nutrientes e íons que não lactatos, a capacidade de ligação foi ligeiramente inferior enquanto se utilizavam meios fermentados em vez de soluções ácidas láticas aquosas.

\section{REFERENCES}

Barker, S. B., Summerson, W.H. (1941), The colorimetric determination of lactic acid in biological materials. Journal Biology and Chemistry, 138, 535554.

Boniardi, N., Rota, R., Nano, G., Mazza, B. (1997), Lactic acid production by electrodialysis I: experimental test. Journal of Applied Electrochemistry, 27, 125-133.

Cao, X. J., Yun, H. S., Koo, Y-M. (2002), Recovery of $\mathrm{L}(+)$-lactic acid by anion exchange resin Amberlite IRA-400. Biochemical Engineering Journal, 11, 189196.

Chen, R. F., Lee, Y. Y. (1997), Membrane-mediated extractive fermentation for lactic acid production from cellulosic biomass. Applied Biochemistry and Biotechnology, 63-65, 435-448.

Davison, B. H., Scott, C. D. (1992), A proposed biparticle fluidised-bed for lactic acid fermentation and simultaneous adsorption. Biotechnology Bioengineering, 39, 365-368.

Evangelista, R. L., Nikolov, Z. L. (1996), Recovery and purification of lactic acid from fermentation broth by adsorption. Applied Biochemistry and Biotechnology, 57, 471-480.

Jeantet, R., Maubois, J. L., Boyaval, P. (1996), Semicontinuous production of lactic acid in a bioreactor coupled with nanofiltration membranes. Enzyme and Microbial Technology, 19, 614-619.

John, R. P., Nampoothiri, K.M., Pandey, A. (2006a), Solid-state fermentation for L-lactic acid production from agro wastes using Lactobacillus delbrueckii. Process Biochemistry, 41, 759 -763.

John, R. P., Nampoothiri, K. M., Pandey, A. (2006b), Simultaneous saccharification and L-(+)-lactic acid fermentation of protease-treated wheat bran using mixed culture of lactobacilli. Biotechnology Letters, 28, 1823-1826.

John, R. P., Nampoothiri, K. M., Pandey, A. (2006c), Simultaneous saccharification and fermentation of cassava bagasse for L-(+)-lactic acid production using lactobacilli. Applied Biochemistry Biotechnology, 134, 263-272.

John, R. P., Nampoothiri, K. M., Pandey, A. (2007a), Fermentative production of lactic acid from biomass: an overview on process developments and future perspectives. Applied Microbiology Biotechnology, 74, 524-534.

John, R. P., Nampoothiri, K. M., Pandey, A. (2007b), Production of $\mathrm{L}(+)$ lactic acid from cassava starch hydrolyzate by immobilized Lactobacillus delbrueckii. Journal of Basic Microbiology, 47, 2530.

John, R. P., Nampoothiri, K. M., Pandey, A. (2007c), Polyurethane foam as an inert carrier for the production of $\mathrm{L}(+)$ lactic acid by Lactobacillus casei under solid state fermentation. Letters in Applied Microbiology, 44, 582-587.

John, R. P., Sukumaran, R. K., Nampoothiri, K. M., Pandey, A. (2007d), Statistical optimization of simultaneous saccharification and $\mathrm{L}(+)$-lactic acid 
fermentation from cassava bagasse using mixed culture of lactobacilli by response surface methodology. Biochemical Engineering Journal, 36, 262-267.

Kaufman, E. N., Cooper, S. P., Clement, S. L., Little, M.H. (1995), Use of a biparticle fluidized-bed bioreactor for continuous and simultaneous fermentation and purification of lactic acid. Applied Biochemistry and Biotechnology, 45-46, 605-620.

Kulprathipanja, S., Oroshar, A. R. (1991), Separation of lactic acid from fermentation broth with an anionic polymeric absorbent. US Patent 5,068,418.

Kwon, Y. J., Kaul, R., Mattiasson, B. (1996), Extractive lactic acid fermentation in poly(ethyleneimine)-based aqueous two-phase system. Biotechnology Bioengineering, 50, 280-290.

Miller, G.L. (1959), Use of dinitrosalicylic acid reagent for determination of reducing sugar. Analatycal Chemistry, 31, 426-429.

Moldes, A. B., Alonso, J. L., Parajo, J. C. (2003), Recovery of lactic acid from simultaneous saccharification and fermentation media using anion exchange resins. Bioprocess and Biosystem Engineering, 25, 357-363.

Nampoothiri, K. M., Singhania, R. R., Sabarinath, C., Pandey, A. (2003), Fermentative production of gellan using Sphingomonas paucimobilis. Process Biochemistry, 38, 1513-1519.

Nomura, Y., Iwahara, M., Hongo, M. (1987), Lactic acid production by electrodialysis fermentation using immobilized growing cells. Biotechnology Bioengineering, 30, 788-793.

Planas, J., Kozlowski, A., Harris, J. M., Tjerneld, F., Barbel, H. H. (1999), Novel polymer-polymer conjugates for recovery of lactic acid by aqueous two-phase extraction. Biotechnology Bioengineering, 66, 211-218.

Rojan, P. J., Nampoothiri, K. M., Nair, A. S., Pandey, A. (2005), L(+)-Lactic acid production using Lactobacillus casei in solid-state fermentation. Biotechnology Letters, 27, 1685-1688.

Russo, J., Kim, L. J., Hyung, S. (1996), Membranebased process for the recovery of lactic acid by fermentation of carbohydrate substrates containing sugars. US Patent 5,503,750.

Siebold, M., Frieling, P. V., Joppien, R., Rindfleisch, D., Schugerl, K., Roper, H. (1995), Comparison of the production of lactic acid by three different lactobacilli and its recovery by extraction and electrodialysis. Process Biochemistry, 30, 81-95.

Thang, V. H., Novalin, S. (2008), Green Biorefinery: Separation of lactic acid from grass silage juice by chromatography using neutral polymeric resin. Bioresource Technology, 99, 4368-4379.

Wee, Y-J., Kim, J-N., Ryu, H-W. (2006), Biotechnological production of lactic acid and its recent applications. Food Technology and Biotechnology, 44, 163-172.

Zihao, W., Kefeng, Z. (1995), Kinetics and mass transfer for lactic acid recovery with anion exchange method in fermentation solution. Biotechnology Bioengineering, 47, 1-7. 